\title{
THE IMPACT OF HERD MANAGEMENT ON MILK HYGIENE OF HOLSTEIN FRIESIAN COWS RAISED UNDER EGYPTIAN CONDITIONS
}

\author{
S.H. El-Kaschab, S.S. Omar, E.M. Ghoniem and M. Elmzyen \\ Department of Animal Production - Faculty of Agriculture - Minoufiya University- Egypt
}

Received: Jan. 11, 2021

Accepted: Jan. 26, 2021

\begin{abstract}
The aim of this study was to investigate the effect of herd management practices on milk quality according to somatic cell count (SCC), standard plate count (SPC) and electrical conductivity (EC). The experimental work was carried out at ElBayoumi dairy farms in Gamasa, Dakahlia Governorate at 2016. Managing cows parity, cows cleanliness score, stocking rate, feeding regime, stage of lactation, daily milk level and milking shift had a higher significant effect on milk hygiene (SCC, SPC and EC) whereas old cows, dirty body cows, overstocked cows, winter and summer feeding regime, higher yielders cows, early and last lactation cows and mid night milking shift had a very poor quality milk (high in somatic cell count, high in Standard plate count and high in Electrical conductivity.
\end{abstract}

Key words: Somatic Cell Count (SCC), Standard plate count (SPC), Electrical Conductivity (EC) and Herd management practices.

\section{INTROUCTION}

High quality raw milk is important to produce higher quality pasteurized milk and dairy products. The production of milk with low bacterial counts starts at the farm and is influenced by many procedures related to on farm management practices. At the farm level, microbial contamination of bulk tank milk (BTM) occurs via 3 main sources: bacterial contamination from the external surface of the udder and teats, from the surface of milking equipments, and from mastitis organisms within the udder (Murphy and Boor, 2000). Measurements such as bacteria levels, somatic cell count (SCC), butterfat, protein and other components are dependent upon management strategies implemented in milking parlor (Galton et al., 1986).

Milk SCC is a key component of national and international regulation for milk quality and an indicator of udder health and of the prevalence of clinical and subclinical mastitis in dairy herds. Somatic cell count from healthy, non- infected glands should be lower than 200,000 cells $/ \mathrm{ml}$ and SCC between 200,000 and 300,000 cells $/ \mathrm{ml}$ is indicative of a degree of infection or initial stages of infection and that general udder health is decreasing (Dohoo and Leslie, 1991) or the cow is infected with a form of mastitis (Smith, 1996). Also, standard plate count (SPC) is an indicator of udder health. Milk is mainly contaminated with bacteria during milking. It is possible to milk animals in such a clean way that the raw milk contains only 500 to 1,000 bacteria per ml. usually the total bacteria count after milking is up to 50,000 per $\mathrm{ml}$. However, counts may reach several millions bacteria per $\mathrm{ml}$. That indicates a very poor hygienic standard during milking and the handling of the milk or milk of a diseased animal with i.e. mastitis (Pandey et al., 2011).

Mastitis is an inflammatory reaction of udder tissue, usually caused by a bacterial infection in the mammary gland (Harmon, 1994, Oliver and Murinda, 2012, Sordillo et al., 1997). This disease alters 
udder secretory processes, lowers milk yield, changes milk composition (Beck et al., 1992, Harmon, 1994), and can be fatal. Mastitis is an important topic in the dairy industry, partly because milk cannot be sold from cows treated with antibiotics, which often occurs with mastitis infections. Milk from treated cows is usually discarded or fed to calves (Blosser, 1979).

There are many reasons why it is important to reduce somatic cell count (SCC) in the dairy cattle population. SCC can result in serious economic losses, impaired animal welfare and consumer and ethical concerns. Consumers now expect their food to come from healthy animals and to be of high quality. Antibiotics are extensively used worldwide for treating clinical mastitis (CM) and SCC, implying an increased risk of residues in milk and of the development of antibiotic resistance, which is considered to be a major public health threat (Hogan, 2005).

The objective of this study was to evaluate associations between milk quality and herd management practices using data collected from El-Bayoumi dairy farms in Gamasa, Dakahila Governorate.

\section{MATERIALS AND METHODS}

This study was conducted on $\mathbf{7 7 9}$ Holstein Friesian cows including 2 lactations belonging to El-Bayoumi dairy farms in Gamasa, Dakahlia Governorate at 2016.

All Cows were fed on a mixture of TMR (Total Mixed Ration) throughout the year with an emphasis on the quality of the feed materials involved in the mix and feed consisting of corn silage, hay and concentrate. Clean water was available ad lib in built basin water. The rations were distributed from 6:00 am to $10 \mathrm{pm}$, and cows don't feed during the milk process. All dairy cows were tested for Tuberculosis (T.B) and Brucella every 6 months and the positive cows were culled from the herd. These cows were tested for clinical and sub clinical mastitis by using California Mastitis Test (CMT) weekly in winter and monthly in summer and the positive cows were segregated and treated by the antibiotics. Reproduction program of these cows was based on estrus synchronization by hormones, Control intra-vaginal Drug Control Release (CIDER). Cows were inseminated artificially within 12-15 hours after the detection of heat using frozen imported semen (Friesian Bulls). Heat detection was the duty of herd's man. Pregnancy diagnosis were determined by rectal palpation and sonar. All cows were housed in 10 loose half shaded barns with clayey bedding and cooling systems (water spray and ventilators). Barn area reach $2340 \mathrm{~m}^{2}(78 \mathrm{~m}$ length $\times 30 \mathrm{~m}$ width) with $30 \mathrm{~m}^{2}$ available space per cow. Barn cleaning out fulfilled monthly in summer and weekly in winter using loader, tractor and trailer.

The cow cleanliness score was evaluated during milking and was based on visual hygienic scores adapted from Nigel B.cook (2010), by independently evaluating 3 areas of each animal's body: the udder, lower leg (rear only), the upper leg and the flank. Score (1) show that the cow is clean (C) and score (2) show that the cow is dirty (D). Dairy cows were housed in two systems with two different stocking rate. The first housing system include cows with high stocking rate (10$30 \mathrm{~m}^{2} /$ cow/ barn) and second group include cows with low stocking rate (31$50 \mathrm{~m}^{2}$ /cow/ barn). milk hygiene were determined for each stocking density.

Cows were classified into seven groups depending on days in milk (DIM) adapted from Harmon (1994) to determine the impact of stage of lactation on the milk hygiene SCC, SPC and EC (Table 1). 
Cows were classified into three groups depending on daily milk production. First group include high yielder cows (>30 kg milk / cow), second group include mid yielder cows $(20-30 \mathrm{~kg} \mathrm{milk/cow})$ and third group include low yielder cows (<20 kg milk/cow). SCC, SPC and EC were estimated for each milk level to determine the impact of milk level on milk hygiene.

Dairy cows were machine milked three times daily at 08.00 a.m., 4.00 p.m., and 12.00 mid night by milking parlor. $18 \mathrm{cow}$ milkers divided into three shifts were used in milking parlor. Each shift managed by 6 milkers ( 2 milkers for udder cleaning, 2 milkers for prestripping and teat disinfection and 2 milkers for clusters positioning). Data of milk hygiene collected from CRYSTAL PROGRAM for each shift to determine the impact of milking shift on milk hygiene.

Milk samples were collected during morning milking (8 a.m), noon milking (4 p.m.) and $\mathbf{1 2 . 0 0}$ mid night milking. A total of 779 milk samples were collected from all lactating cows during summer and winter. Samples were collected according to the National Mastitis Council (2001). Sample from each cow were transported to the laboratory of the Animal Reproduction Research Institute (ARRI) in ice-cooled box and analyzed immediately (max $6 \mathrm{~h}$ after collection) for SCC, SPC by using Milko Scan ${ }^{\text {TM }}$ (FT2. 2013). In this study electrical conductivity was determined in milk during the milking by the CRYSTAL MILKING PROGRAM SYSTEM for all cows each shift milking and the data collected from the computer in summer and in winter.

\section{Statistical analysis and model}

Data were statistically analyzed using SPSS 20.0. Pearson correlations among defined characteristics were also estimated using SPSS 20.0.
Significant differences among means were assigned according to Duncun (1955).

\section{Statistical Models}

The following models were used:

$Y_{i j k l m n x o}=\mu+T_{i}+l_{j}+F_{k}+B_{l}+P_{m}+S_{n}+M_{X}$

Where:

$$
+L_{o X}+e_{i j k I m n x o}
$$

$Y_{i j k l m n x o}=$ Somatic cell count (SCC) Standard plate count (SPC) Electrical conductivity (EC)

$\mu=$ Population mean.

$T_{i}=$ The fixed effect of the ith Parity, ( $i=$ $1,2,3,4,5)$.

$I_{j}=$ The fixed effect of the $j t h$ Cow cleanliness score, $(j=1,2)$.

$F_{k}=$ The fixed effect of the kth Stocking rate, $(k=1,2)$.

$B_{I}=$ The fixed effect of the Ith Feeding regime, $(I=1,2)$.

$P_{m}=$ The fixed effect of the mth milk level, $(m=1,2,3)$.

$S_{n}=$ The fixed effect of the $n t h$ stage of lactation, ( $n=1,2,3,4,5,6,7)$.

$M_{X}=$ The fixed effect of the $x t h$ milking shift, $(X=1,2,3)$.

$L_{o X}=$ available interactions

$\boldsymbol{e}_{i j k l m n x o}=$ Random error assumed to be independent normally distributed with mean and variance.

\section{RESULTS AND DISCUSSION}

\section{Managing cows parity}

Cows parity revealed a highly significant effect $(P<0.001)$ on Somatic cell count (SCC), Standard plate count (SPC) and Electrical conductivity (EC) in milk (Table 1and Figures 1,2) whereas SCC for cows in the $1^{\text {st }}, 2^{\text {nd }}, 3^{\text {rd }}, 4^{\text {th }}$ and $\geq 5^{\text {th }}$ parities were $288.5 \pm 4.1,294.1 \pm 5.9$, $318.4 \pm 9.3,323.75 \pm 17$ and $318.3 \pm$ $11 \times 10^{3} \mathrm{cell} / \mathrm{ml}$ milk, respectively. However, milk SPC were 101.2 \pm 3.3 , 94.4 $\pm 3.6, \quad \quad 116.8 \pm 9.2,139.45 \pm 18$ and $110.3 \pm 10 \times 10^{3} \mathrm{cell} / \mathrm{ml}$ milk, respectively and milk EC were 4.14 $\pm 0.04,4.17 \pm 0.06$, $4.51 \pm 0.09,4.66 \pm 0.07$ and $4.61 \pm 0.09$ $\mathrm{ms} / \mathrm{cm}$ milk, respectively. 
S.H. El-Kaschab, et al.,

Table 1. Least squares mean (LSM) \pm Standard errors (SE) for milk SCC, SPC and EC according to different herd management criteria.

\begin{tabular}{|c|c|c|c|c|}
\hline \multirow[b]{2}{*}{$\begin{array}{c}\text { Herd management } \\
\text { criteria }\end{array}$} & \multicolumn{4}{|c|}{$\begin{array}{c}\text { Milk Hygiene } \\
\end{array}$} \\
\hline & $\begin{array}{l}\text { Animals } \\
\text { number }\end{array}$ & $\begin{array}{c}\text { SCC } \times 1000 \text { cell } \\
/ / \text { l milk } \\
(\bar{X} \pm \mathrm{SE})\end{array}$ & $\begin{array}{c}\text { SPC } \times 1000 \text { cell } \\
/ / \mathrm{ml} \text { milk } \\
(\bar{X} \pm \mathrm{SE})\end{array}$ & $\begin{array}{c}\mathrm{EC}(\mathrm{ms} / \mathrm{cm}) \\
(\bar{X} \pm \mathrm{SE})\end{array}$ \\
\hline$\mu$ & 1437 & $300.3 \pm 12$ & $105.7 \pm 4.5$ & $4.25 \pm 0.05$ \\
\hline \multicolumn{5}{|c|}{ Managing cow parity } \\
\hline $1^{\text {st }}$ & 573 & $288.5 \pm 4.1^{\mathrm{a}}$ & $101.2 \pm 3.3^{\mathrm{a}}$ & $4.14 \pm 0.04^{a}$ \\
\hline $2^{\text {nd }}$ & 391 & $294.1 \pm 5.9^{\mathrm{ab}}$ & $94.4 \pm 3.6^{\mathrm{a}}$ & $4.17 \pm 0.06^{a}$ \\
\hline $3^{\text {rd }}$ & 210 & $318.4 \pm 9.3^{b c}$ & $116.8 \pm 9.2^{\mathrm{a}}$ & $4.51 \pm 0.09^{c}$ \\
\hline $4^{\text {th }}$ & 120 & $323.75 \pm 17^{c}$ & $139.45 \pm 18^{b}$ & $4.66 \pm 0.07^{c}$ \\
\hline$\geq 5^{\text {th }}$ & 143 & $318.3 \pm 11^{b c}$ & $110.3 \pm 10^{a}$ & $4.61 \pm 0.09^{c}$ \\
\hline Significance & & $\star \star \star \star ~$ & $\star \star \star \star ~$ & $\star \star \star \star$ \\
\hline \multicolumn{5}{|c|}{ Cow cleanliness score } \\
\hline Clean & 489 & $246.1 \pm 3.2$ & $60.5 \pm 0.9$ & $3.51 \pm 0.01$ \\
\hline Dirty & 948 & $328.3 \pm 5.1$ & $129.1 \pm 1.5$ & $4.62 \pm 0.05$ \\
\hline Significance & & $\star * \star x$ & 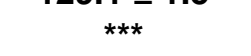 & 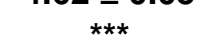 \\
\hline \multicolumn{5}{|c|}{ Stocking rate } \\
\hline High density & 686 & $306 \pm 0.9$ & $106 \pm 1$ & $4.54 \pm 0.01$ \\
\hline Low density & 751 & $288.8 \pm 5.1$ & $85.72 \pm 5$ & $3.84 \pm 0.05$ \\
\hline Significance & & 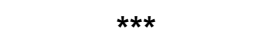 & $\star \star \star *$ & $\star \star \star$ \\
\hline \multicolumn{5}{|c|}{ Managing feeding regimes } \\
\hline Summer ration & 658 & $317.5 \pm 3.6$ & $120 \pm 3.1$ & $4.7 \pm 0.04$ \\
\hline Winter ration & 779 & $324.6 \pm 5$ & $127.1 \pm 4.3$ & $4.69 \pm 0.04$ \\
\hline Significance & & NS & NS & NS \\
\hline \multicolumn{5}{|c|}{ Stage of lactation } \\
\hline 0-49 DIM & 65 & $323.2 \pm 12.8^{\mathrm{a}}$ & $135.5 \pm 13.7^{c}$ & $4.98 \pm 0.1^{\mathrm{c}}$ \\
\hline 50-99 DIM & 187 & $324.7 \pm 12.4^{\mathrm{a}}$ & $136 \pm 10.6^{c}$ & $4.99 \pm 0.09^{b}$ \\
\hline 100-149DIM & 133 & $328.45 \pm 16.9^{a}$ & $142 \pm 15.5^{c}$ & $5.01 \pm 0.1^{\mathrm{c}}$ \\
\hline 150-199 DIM & 204 & $284.6 \pm 8.8^{b}$ & $90.5 \pm 7.1^{\mathrm{ab}}$ & $3.95 \pm 0.8^{\mathrm{a}}$ \\
\hline 200-249DIM & 266 & $271.5 \pm 6.2^{b}$ & $82.3 \pm 5.4^{\mathrm{a}}$ & $3.81 \pm 0.07^{\mathrm{a}}$ \\
\hline 250-300 DIM & 161 & $274.9 \pm 6.9^{b}$ & $84.2 \pm 6.7^{\mathrm{a}}$ & $3.75 \pm 0.09^{\mathrm{a}}$ \\
\hline >300 DIM & 421 & $312.4 \pm 4.2^{\mathrm{a}}$ & $113.5 \pm 3.2^{b c}$ & $4.53 \pm 0.04^{b}$ \\
\hline Significance & & 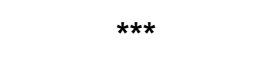 & $\star \star \star ~$ & 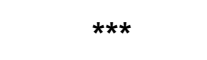 \\
\hline \multicolumn{5}{|c|}{ Daily milk Level } \\
\hline High level (>30 kg & 649 & $301.4 \pm 4^{a}$ & $108.4 \pm 3.8^{\mathrm{a}}$ & $4.26 \pm 0.04^{a}$ \\
\hline (Medium level (20- & 696 & $261.2 \pm 1.7^{b}$ & $72.4 \pm 1.4^{\mathrm{b}}$ & $3.9 \pm 0.03^{b}$ \\
\hline Low level (<20 kg & 92 & $522 \pm 3.4^{c}$ & $286.2 \pm 19^{c}$ & $6.17 \pm 0.1^{c}$ \\
\hline Significance & & $\star * \star$ & $\star \star \star$ & *** \\
\hline \multicolumn{5}{|c|}{ Managing milking shift } \\
\hline Group A & 480 & $294.2 \pm 1.1^{\mathrm{a}}$ & $87.4 \pm 2.2^{\mathrm{a}}$ & $3.84 \pm 0.05^{a}$ \\
\hline Group B & 478 & $325.2 \pm 1.9^{b}$ & $111.1 \pm 2.6^{b}$ & $4.78 \pm 0.06^{b}$ \\
\hline Group C & 479 & $362.2 \pm 1.7^{c}$ & $156.5 \pm 2.9^{c}$ & $6.81 \pm 0.001^{c}$ \\
\hline Significance & & $\star * *$ & $\star \star \star$ & 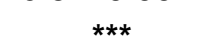 \\
\hline
\end{tabular}




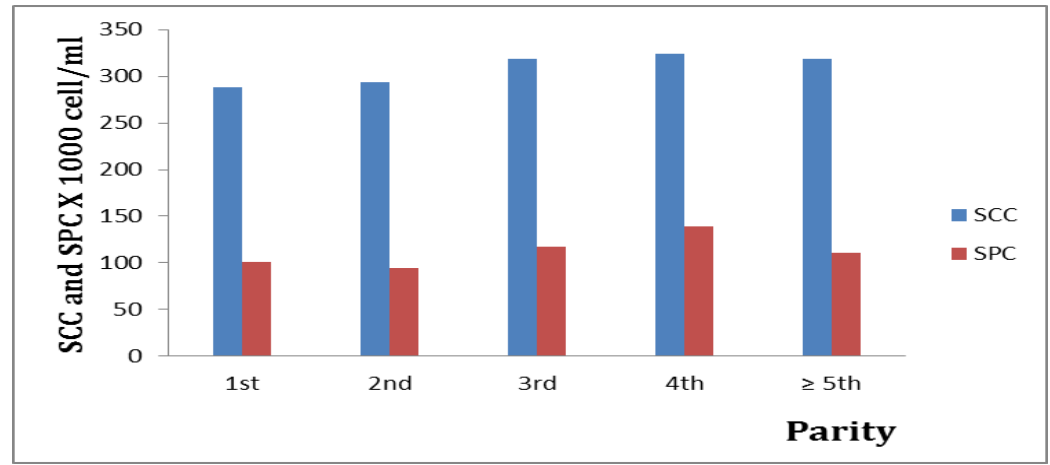

Fig (1): SCC and SPC for different parities.

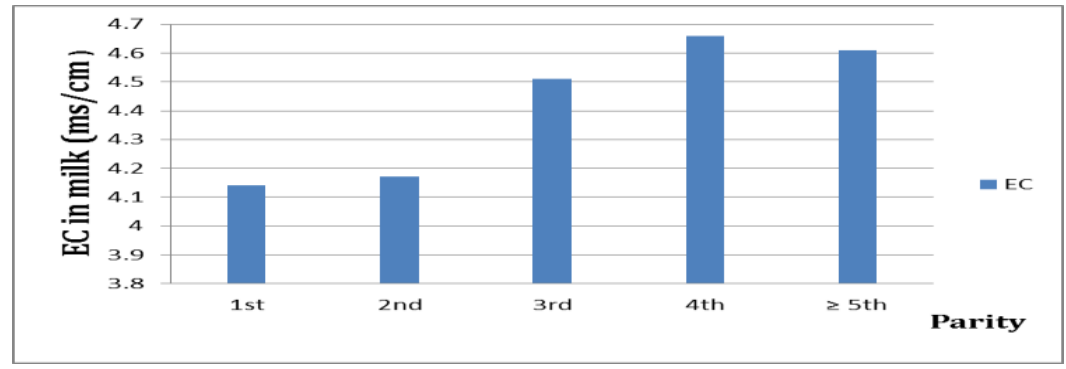

Fig (2): Electrical conductivity for different parities.

Results in Table 1 and Figure 1,2 indicate SCC, SPC and EC are increased with advanced parities whereas SCC SPC and EC begins low in the first lactation and then begins to rise to reach maximum level in the fourth lactation the reason could be attributed to that mammary gland immunity of older cows were lower than primiparous subsequently multiparous are vulnerable for mastitis infection more than young cows. These results were in agreement with Gonçalves et al., 2018 and Dang et al., 2014 whose reported that, young primiparous karan Fries crossbreed cows produce less milk and have a lower milk SCC as compared to multiparous cows and the mammary gland immunity of primiparous cows is always higher as compared to the multiparous cows throughout the lactation period.

\section{Managing housing systems \\ Cows cleanliness score}

Cow cleanliness scores revealed a highly significant effect $(P<0.001)$ on milk
SCC, SPC and EC (Table 1). SCC for clean and dirty score cows were $246.1 \pm$ 3.2 and $328.3 \pm 5.1 \times 10^{3} \mathrm{cell} / \mathrm{ml} \mathrm{milk}$, respectively. Also, milk SPC were $60.5 \pm$ 0.9 and $129.1 \pm 1.51 \times 10^{3} \mathrm{cell} / \mathrm{ml} \mathrm{milk}$ for clean and dirty score cows, respectively. However, milk EC were count for $3.51 \pm$ 0.01 and $4.62 \pm 0.05 \mathrm{~ms} / \mathrm{cm}$ milk for clean and dirty score cows, respectively.

Results in Table 1 (Figures 3,4) indicated that, whenever the cows cleanliness score decrease the contamination of cows increase subsequently the percent of mastitis infection increase according to increasing in SCC and SPC. Increasing SCC and SPC leads to produce very poor quality milk (low fat, casein and lactose). These results were in agreement with that reported by Barkema et al., (1998) who revealed that, the environment and the Holstein cows themselves were cleaner for herd that produced milk with lower SCC values compared with herds with higher bulk tank SCC values. 


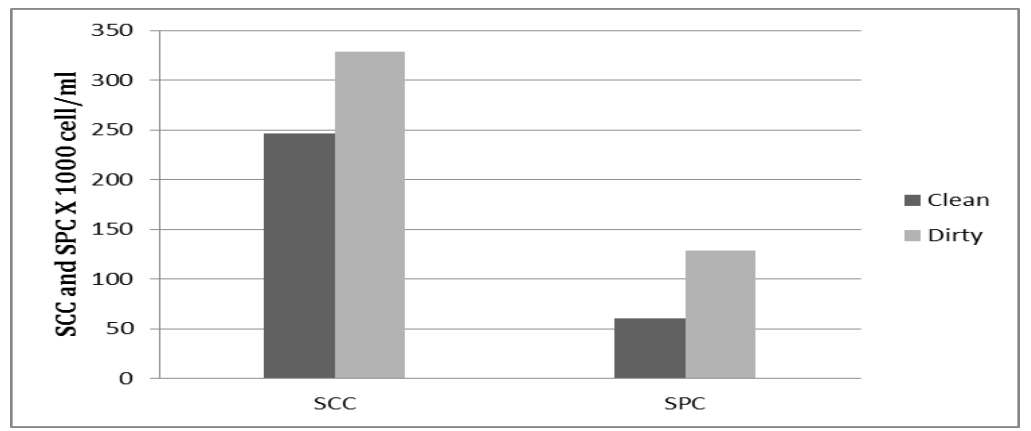

Fig (3): SCC and SPC for different cow cleanliness scores.

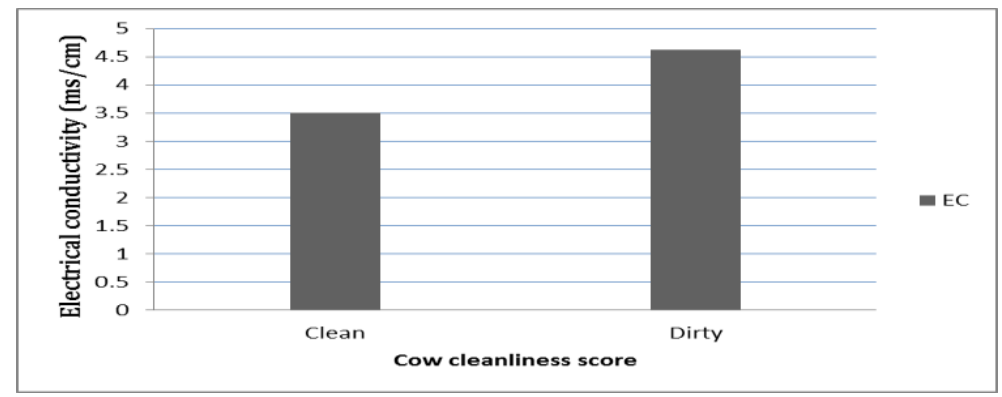

Fig (4): EC for different cow cleanliness scores.

\section{Stocking rate}

Stocking rate has a highly significant effect $(P<0.001)$ on SCC, SPC and EC in milk (Table 1 and Figure 5,6). SCC in milk for cows with stocking rate $10-30 \mathrm{~m}^{2} / \mathrm{cow}$ and $31-50 \mathrm{~m}^{2} / \mathrm{cow}$ were $306 \pm 0.9$ and $288.8 \pm 5.1 \quad \times 10^{3}$ cell $/ \mathrm{ml}$ milk ,respectively. However, milk SPC were $106 \pm 1$ and $85.72 \pm 5$ for high density and low density stocking rate, respectively. On the other hand milk EC were $4.54 \pm$ 0.01 and $3.84 \pm 0.05$ for high density and low density stocking rate, respectively. Overstocking cows increased the amount of manure in the barn and the contamination of lying surface, which increased in tern bacteria count on teat ends and increased the risk of udder infection. These results were in agreement with Hill et al (2007) who showed that milk quality was affected by overstocking in Holstein cows, however Krawczel and Grant (2009) reported that somatic cell count (SCC) in Holstein cow's milk increase to $113 \%$. This increasing occurs as a result of increase in the number of mastitis cases in cows that have stocking rate of $142 \%$ compared to cows that have $100 \%$.

\section{Managing milk production Stage of lactation}

Stage of lactation has a highly significant effect $(P<0.001)$ on SCC, SPC and EC in milk (Table1 and Figure 7, 8). SCC for cows with different stage of lactation (0-49, 50-99, 100-149, 150-199, 200-249, 250-299 and $>300$ day in milk) were $323.2 \pm 12.8,324.7 \pm 12.4,328.45 \pm$ 16.9, $284.6 \pm 8.8,271.5 \pm 6.2,274.9 \pm 6.9$ and $312.4 \pm 4.2 \times 10^{3}$ cell $/ \mathrm{ml}$ milk, respectively. On the other hand milk SPC for the same trends were $135.5 \pm 13.7$, $136 \pm 10.6,142 \pm 15.5,90.5 \pm 7.1,82.3 \pm$ $5.4,84.2 \pm 6.7$ and $113.5 \pm 3.2 \times 10^{3} \mathrm{cell} / \mathrm{ml}$ milk, respectively. However, milk EC were $4.98 \pm 0.1,4.99 \pm 0.09,5.01 \pm 0.1$, $3.95 \pm 0.8, \quad 3.81 \pm 0.07,3.75 \pm 0.09$ and $4.53 \pm 0.04 \mathrm{~ms} / \mathrm{cm}$ milk for the same trend, respectively. SCC, SPC and EC 
increased during early and late stage of lactation. The reason may due to that early lactation was linked with high milk production in this period where the cows are strained and low immunity subsequently cows are venerable for mastitis infections. Also, in late stage of lactation the restoration of alveoli cells increases subsequently increase the contamination on milk. These results were in agreement with Dohoo and Meek, 1982 who showed that SCC of Black Holstein cows increases with progressing lactation (late lactation) regardless of whether the cow is infected or not.

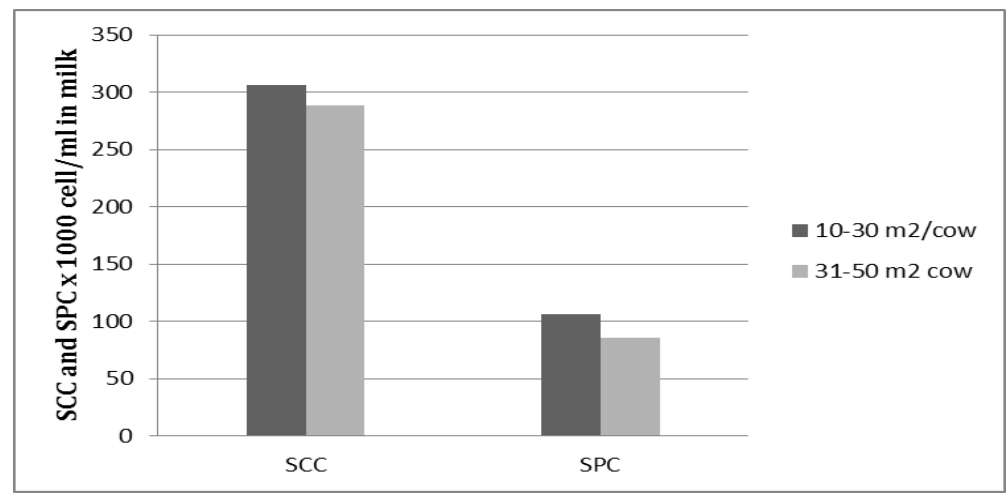

Fig (5): SCC and SPC for different stocking rates.

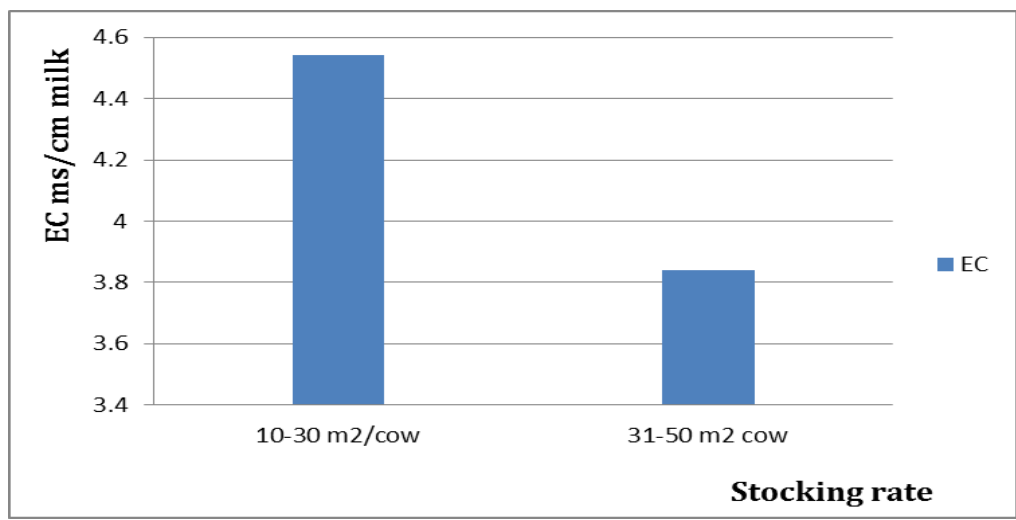

Fig (6): EC for different stocking rates.

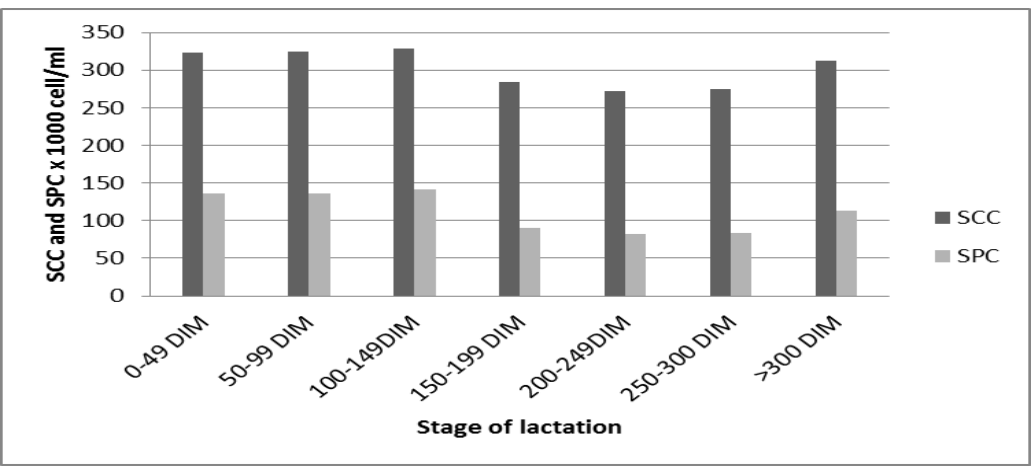

Fig (7): SCC and SPC for different stages of lactation. 


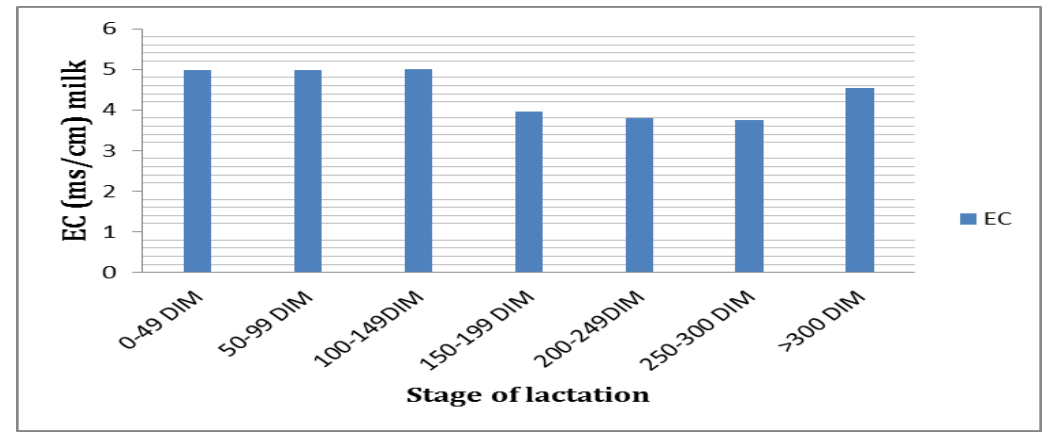

Fig (8): EC for different stages of lactation.

\section{Daily Milk level}

Daily milk level of cows revealed highly significant effect $(P<0.001)$ on SCC, SPC and EC in milk (Table 1, Figures 9,10 ) whereas SCC for cows with high, medium and low level daily milk level were $301.4 \pm 4,261.2 \pm 1.7$ and $522 \pm$ $3.4 \times 10^{3}$ cell $/ \mathrm{ml}$ milk, respectively. On the other hand, SPC for the same trend of cow's milk level were $108.4 \pm 3.8,72.4 \pm$ 1.4 and $286.2 \pm 1.9 \times 103$ cells $/ \mathrm{ml}$ milk, respectively. However the trends for milk EC were $4.26 \pm 0.04,3.9 \pm 0.03$ and $6.17 \pm$ $0.1 \mathrm{~ms} / \mathrm{cm}$ milk, respectively.

Cows with low and high milk level show increasing the incidence of mastitis and are at a greater risk of developing clinical and subclinical mastitis. High milk production cows are strained and low immunity subsequently cows are venerable for mastitis infections. These results were in agreement with Mukherjee and Dang (2011) who reported that high milk-producing Holstein cows are under stress of milk production, and their immunity becomes low leading to more SCC in their milk. During late lactation the renewable of mammary gland increase subsequently SCC increase on milk because of increasing neutrophils increase and lymphocytes decrease. These results were in agreement with McDonald and Anderson (1981) who reported that during late lactation the percentage of neutrophils tends to increase while the percentage of lymphocytes decreases.

\section{Managing feeding regime}

Feeding regime (Table 1) revealed no significant impact on SCC, SPC and EC, whereas SCC for cows with summer and winter feeding regime were $317.5 \pm 3.6$ and $324.6 \pm 5 \times 10^{3} \mathrm{cell} / \mathrm{ml}$ milk, respectively. However, SPC in summer and winter feeding regime were $120 \pm 3.1$ and $127.1 \pm 4.3 \times 10^{3} \mathrm{cell} / \mathrm{ml}$ milk, respectively. Furthermore, milk EC were $4.7 \pm 0.04$ and $4.69 \pm 0.04 \mathrm{~ms} / \mathrm{cm}$ milk for summer and winter feeding, respectively. Generally, there was high bacteria contamination in milk in both summer and winter which may be due to temperature and humidity which subsequently increase the infection of mastitis. These results were in agreement with that reported by Morse et al. (1988) who found that SCC of Holstein cows is highest in spring and summer because of extreme temperatures and high humidity which lead to poor fodder quality and may also cause more growth of the bacteria infectious accompanied with low immunity. Unfortunately, there was high milk contamination in winter according to high calving season and high milk yield which subsequently leads to increase mastitis infection in winter. Furthermore, Clements et al. (2005) reported that the highest SCC around the period of calving was observed in winter, and the lowest SCC in these herds occurred shortly after calving period. 


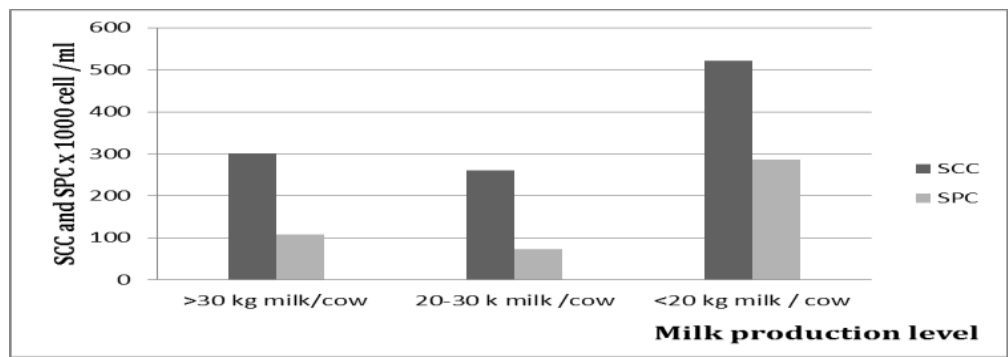

Fig (9): SCC and SPC for different milk levels.

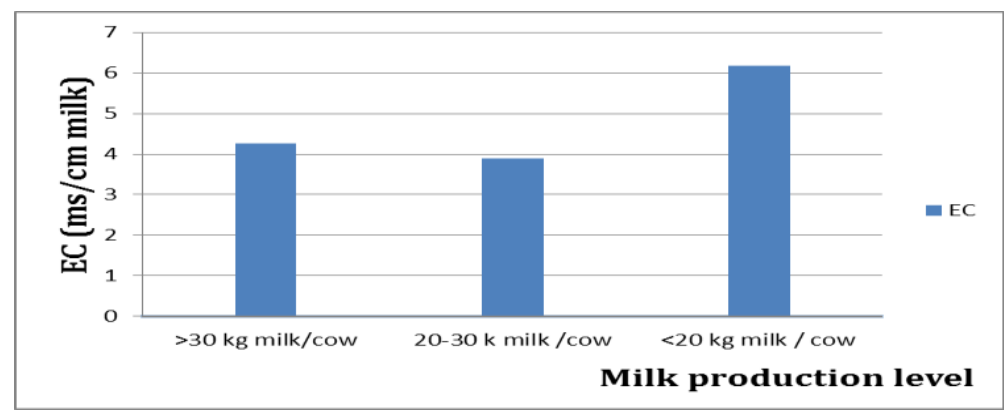

Fig (10): EC for different milk levels.

\section{Managing milking shift}

Milker's shifts has a highly significant effect $(P<0.001)$ on milk SCC, SPC and EC (Table 1), whereas SCC for cows that milked by milker's shifts (A, B and C) were $294.2 \pm 1.1,325.2 \pm 1.9$ and $362.2 \pm$ $1.7 \times 10^{3} \mathrm{cell} / \mathrm{ml}$ milk, respectively. On the other hand, SPC for cows that milked by milker's shifts (A, B and C) were $87.4 \pm$ $2.2,111.1 \pm 2.6$ and $156.5 \pm 2.9 \times$ $10^{3} \mathrm{cell} / \mathrm{ml} \mathrm{milk}$, respectively. Also, EC for cows that milked by milker's shifts (A, B and $C$ ) were $3.84 \pm 0.05,4.78 \pm 0.06$ and $6.81 \pm 0.001 \mathrm{~ms} / \mathrm{cm}$ milk, respectively. Table 1 indicated that milkers of group A was the cleanest in milking and the least contaminated milk compared to Group B and Group C. This difference may due to that milker moves from one animal to the next subsequently can transfer pathogenic micro-organisms to all the animals in the herd. Also this variation may associated with contagious disease on French Friesian cows, wear clean clothes and have trimmed and clean nails and wash hands with soap and water before milking and dry them with a clean towel (Pandey et al., 2011). These results were in agreement with Barkema et al., 1998 who showed that, the people that work in the milking parlor of Holstein cows have the primary responsibility for mastitis control while other workers are responsible for stall maintenance and feeding.

\section{Interactions within criteria studied on milk hygiene.}

All interactions within criteria studied (Table 2) on milk hygiene were highly significant $(P<0.001)$. It is obviously clear that the influence of all criteria studied interacting together on milk hygiene. Managing such criteria are very difficult and complicated. Manager should be carefully handle with those criteria as an integrated task and not as individual one.

Cow cleanliness has a highly significant effect on milk hygiene. This may be due to increased contamination in the barn, due to the high density, the contamination of cows increases especially in the udder. This leads to an increase of infection of mastitis as a result of bacteria interning the teat ends. 
Table 2. Interactions within criteria studied on milk hygiene

\begin{tabular}{|c|c|}
\hline Interaction & Significant \\
\hline Feeding regime $x$ cow cleanliness score & 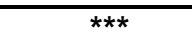 \\
\hline Feeding regime $\mathrm{x}$ parity & *** \\
\hline Feeding regime $\mathrm{x}$ stocking rate & *** \\
\hline Feeding regime $\mathrm{x}$ milk level & *** \\
\hline Feeding regime $\mathrm{x}$ milking shift & *** \\
\hline Parity $\mathrm{x}$ stocking rate & *** \\
\hline Cow cleanliness score $\mathrm{x}$ parity & *** \\
\hline parity $x$ stocking rate $x$ feeding regime & *** \\
\hline
\end{tabular}

${ }^{\star \star *}=$ high significant $(P<0.001)$

On the other hand, feeding regime and parity interact highly significant $(P<0.001)$ on milk hygiene (Table 2). This may be due to the advancement of parities and aging of cows, the increasing of mastitis infection which associated with reduced immunity by advanced age.

Furthermore, the interaction between feeding regime and stocking rate $(P<0.001)$ on milk hygiene (SCC, SPC and EC) may be due to the highly significant effect of stocking rate on milk hygiene. With increasing barns density, the chance of cow's contamination increases, and consequently, the rate of mastitis infection increases. Also, the interaction between feeding regime and milk level $(P<0.001)$ on milk hygiene may be due to the highly significant effect of milk level on milk hygiene. Highly productive cows are strained as results of high milk production, so their immunity is weak and therefore vulnerable to mastitis.

On the other hand, the interaction between feeding regime and milking shift $(P<0.001)$ on milk hygiene may be due to the highly significant effect of milking shift on milk hygiene. The lack of milkers cleanliness and failure to follow the correct steps for milking process lead to increase milk contamination. Interaction between stocking rate and parity $(P<0.001)$ on milk hygiene (SCC, SPC and
EC) may be due to that overstocking was higher in winter than in summer and periodic cleanout of barns in winter and also, increase the milking times of fresh cows may decrease contamination in milk. In despite of advanced parities increase the contamination of milk, there were cows with advanced parities that had higher quality milk, this may be attributed to good care for these cows during the milking process, attention for the correct milking steps. The periodic examination for these advanced parities cows by using CMT decrease the milk contamination and mastitis infection.

The interaction between cow cleanliness and parity $(P<0.001)$ on milk hygiene mean despite of dirty cow cleanliness score of these cows but contamination in milk was decreased. This may be related to washing the dirty cows before milking processes and attention for correct milking which steps decrease the contamination in milk for these cows. Also, despite of clean cow cleanliness score of these cows but contamination in milk was increase this may be due to late stage of lactation for these cows whereas the cows in late lactation have poor quality milk.

\section{CONCLUSION AND FUTURE PRESPECTIVE}

From this study it could be concluded that good herd management practices 
had positive effect on increasing milk yield, decreasing mastitis infection and increasing milk composition such as fat, casein and lactose yield which could be reflected on better performance and economic return and helping breeders for organizing dairy herd to get the best income.

\section{REFERENCES}

Barkema, H.W., Y.H. Schukken, T.J.G.M. Lam, M.L. Beiboer, G. Benedictus and A. Brand (1998). Management practices associated with low, medium and high somatic cell count in bulk milk. J Dairy Sci. 81: 19171927.

Beck, H. S., W. S. Wise and F. H. Dodd (1992). Cost benefits analysis of bovine mastitis in the UK. J. Dairy Res. 59 (04):449-460.

Blosser, T. H. (1979). Economic losses from and the national research program on mastitis in the United States. J. Dairy Sci. 62 (1):119-127.

Clements, A.C.A., D.U. Pfeiffer and D. Hayes (2005). Bayesian spatiotemporal modelling of national milkrecording data of seasonal-calving New Zealand dairy herds Prev. Vet. Med., 71: 183-196.

Dang, A.K., J. Mukherjee, M. Chaudhury, P. Shiv, A.K. Mohanty, S. Kapila and R. Kapila (2014). In vitro phagocytic activity of blood and milk neutrophils against Saccharomyces cerevisiaein primiparous and multiparous Karan Fries crossbred cows throughout the dry period and lactation cycle. Indian J. Anim. Sci.,84: 262-266.

Dohoo, I. R. and A. H. Meek (1982). Somatic cell counts in bovine milk. Can. Vet. J. 23(4):119-125.

Dohoo, I.R. and Leslie K.E. (1991). Evaluation of changes in somatic cell counts as indicators of new intramammary infections. Preventive
Veterinary Medicine 10:225-238.

Duncan, D. B. (1955). Multiple Range and Multiple F Test. Biometrices11:1.

Galton, D.M., L.G. Peterson and W.G. Merrill (1986). The Effects of Premilking Udder Preparation Practices on Bacterial Counts in Milk and on Teats. J. Dairy Sci.101, pp. 3624-3632.

Goncalves, J.L., R.I. Cue, B.G. Botaro, J.A. Horst, A.A. Valloto and M.V. Santos (2018). Milk losses associated with somatic cell counts by parity and stage of lactation. J. Dairy Sci., 80 : 3219.

Harmon, R.J. (1994). Symposium Mastitis and Genetic Evaluation for Somatic Cell Count - Physiology of Mastitis and Factors Affecting Somatic Cell Counts. Journal of Dairy Science 77(7), 2103-2112.

Hill, C.T., P.D. Krawczel, H.M. Dann, C.S. Ballard, R.C. Hovey and R.J. Grant (2007). Effect of stocking density on the short-term behavior of dairy cows. J. Dairy Sci. 90 (Suppl. 1): 244.

Hogan. J. (2005). Human health risks associated with high somatic cell count: symposium summary. [Online] NMC Board of Directors Report, National Mastitis Council, Verona, Wisconsin. Available from: http://www nmconline.org/docs/scchealthrisks.pd f[Accessed June 16 2009].

Krawczel, P. and R. Grant (2009). Effects of cow comfort on milk quality, productivity and behavior. Pages 1524 in NMC Annual Meeting Proceedings.

McDonald, J. S. and A. J. Anderson (1981). Total and differential somatic cell counts in secretions from noninfected bovine mammary glands; the peripartum period. Am. J. Vet. Res. 42:1366-1368.

Morse, D., M.A. De Lorenzo, C.J. Wilcox, R.J. Collier, R.P. Natzke and D.R. Bray (1988). Climatic effects on occurrence 
of clinical mastitis. J. Dairy Sci., 71: 848-853.

Mukherjee, J. and A.K. Dang (2011). Immune activity of milk leukocytes during early lactation period in high and low yielding crossbred cows. Milchwissenschaft, 66: 384-388.

Murphy, S.C. and K.J. Boor (2000). Trouble-shooting sources and causes of high bacteria counts in raw milk. Dairy Food Environ. Sanit. 20, 606-611.

National Research Council. (1989). Nutrient Requirement of Daily cattle $6^{\text {th }}$ rev. ed. Natl. Acad. Sci. Washington, D.C.

National Mastitis Council (2001). National mastitis council recommended mastitis control.

Nigel, B. Cook (2010). The influence of barn design on dairy cow hygiene, lameness and udder health. University of Wisconsin - Madison WI 53:37-46.

Oliver, S. P. and S. E. Murinda (2012). Antimicrobial resistance of mastitis pathogens. Vet Clin Food Animal 28:165-185.

Pandey, Dairy Development Specialist, G.C.J. Voskuil, Animal Husbandry Specialist. (2011). Manual on milk safety, quality and hygiene. Golden Valley Agriculture Research Trust (GART).

Smith, K.L. (1996). Standards for somatic cells in milk; physiological and regulatory. Mastitis Newsletter, Newsletter of the ID, 144: 7.

Sordillo, L. M., K. Shafer-Weaver and D. DeRosa (1997). Immunobiology of the mammary gland. J. Dairy Sci. 80 (8):1851-1865. 
تأثير ادارة القطيع علي نظافة لبن أبقار الهولستين فريزيان المرياة تحت الظروف المصرية

سمير حسن الخشاب، سعيد سعيد عمر، إلهام محمد غنيم، محمود عبدالرحمن المزين

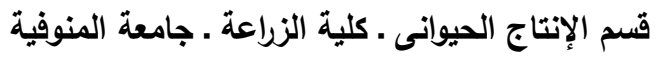

$$
\text { الملخص العربي }
$$

أجريت هذة الدراسةعلي عدد VVq بقرة من سلالة الهولثتين فريزيان في مزرعة البيومي بمدينة جمصة التابعة

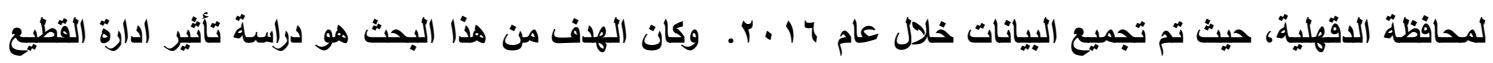

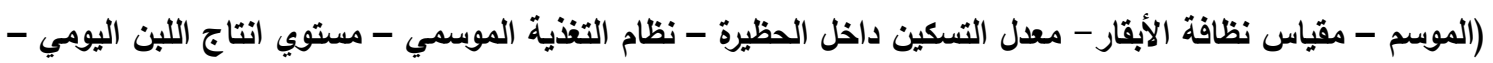
مرحلة الحليب - تأثير ميعاد الحلبة) علي نظافة اللبن من حيث محتواه من الخلايا الجسمية والعدد البكتيري ومعامل

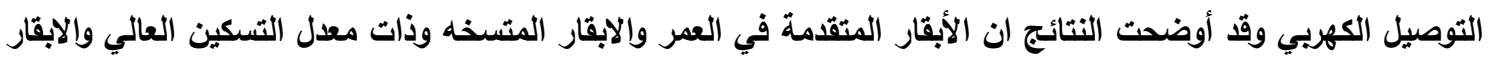

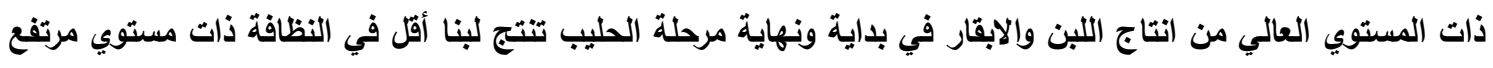
من الخلايا الجسمية والعدد البكتيري ومعامل التوصيل الكهربي. 